\title{
THE COMPLETE PRIMARY STRUCTURE OF PROTEIN SYNTHESIS INHIBITOR II FROM BARLEY SEEDS
}

\author{
by \\ KATSUHIKO ASANO", BIRTE SVENSSON, IB SVENDSEN, \\ FLEMMING M. POULSEN \\ and \\ PETER ROEPSTORFF ${ }^{2)}$ \\ Department of Chemistry, Carlsberg Laboratory, \\ Gamle Carlsberg Vej 10, DK-2500 Copenhagen Valby \\ 1) Present address: Applied Bioscience Laboratory, Kirin Brewery Co., Ltd., \\ 2-2, Soujamachi Ichome, Maebashi-shi, 371 Japan \\ 2) Department of Molecular Biology, University of Odense, Campusvej 55, DK-5230, Odense
}

\begin{abstract}
Keywords: Gas-phase sequencing, RP-HPLC, acetylated N-terminal, mass spectrometry, sequence homology
\end{abstract}

\begin{abstract}
The complete amino acid sequence of the barley translation inhibitor II has been determined. Peptide fragments were generated by cleavage with either cyanogen bromide, hydroxylamine, o-iodosobenzoic acid, $\mathrm{S}$. aureus V8 protease, endoproteinase Lys-C, clostripain, or trypsin. The fragments were separated by gel filtration and RP-HPLC and subjected to automated liquid phase sequencing, gas-phase sequencing or mass spectrometry. The translation inhibitor possessed a blocked $\mathrm{N}$-terminus identified as acetylated alanine by mass spectrometry of an $\mathrm{N}$-terminally blocked tetrapeptide generated by cleavage with cyanogen bromide. Barley translation inhibitor II consists of 280 amino acid residues in a single chain and shows a distant homology to the ricin A-chain.
\end{abstract}

\section{INTRODUCTION}

Barley seeds contain three closely related inhibitors of cell-free animal protein synthesis (1). The inhibitors are N-terminally blocked, single chain basic polypeptides with $M_{r} \sim 30,000$ which in catalytic amounts inhibit the elongation phase of polypeptide synthesis $(2,17)$. Functionally related proteins have been isolated from a wide variety of plants. They are either heterodimeric cytotoxins, consisting of an A- chain responsible for arrest of translation and a B-chain possessing cytoagglutinating activity, or monomeric proteins capable of inactivating animal cell-free protein synthesis systems (3, 23). Ricin from castor bean is so far the only one of these inhibitors for which the complete primary structure has been described $(9,10)$. Recently, sequences of approx. $30 \mathrm{~N}$-terminal residues were reported for single polypeptide chain inhibitors from Phytolacca americana, Phyto-

Abbreviations: DFP = diisopropyl fluorophosphate; DPCC = diphenyl carbamyl chloride; EDTA = ethylenediamine tetraacetic acid, disodium salt; $\mathrm{PAGE}=$ polyacrylamide gel electrophoresis; $\mathrm{PAP}=$ pokeweed antiviral protein; PTH- = phenylthiohydantoin-; RP-HPLC = reverse phase high performance liquid chromatography; SDS = sodium dodecyl sulfate; Tris = 2-amino-2-hydroxymethylpropane-1,3-diol. 
lacca dodecandra and Saponaria officinalis as well as for the A-chain of modeccin from Modecca digitata $(4,11,14,18,19)$. Despite the short regions analyzed the sequence homology with the ricin A-chain was significant, suggesting these proteins to have evolved from a common ancestor.

In the present study the primary structure of the dominant barley translation inhibitor II was determined by protein sequencing. This, as far as we know, is the first reported complete sequence of a single polypeptide chain translation inhibitor from higher plants. It shows distant homology with the ricin A-chain as well as with the $\mathrm{N}$-terminal sequences reported for the other plant translation inhibitors.

\section{MATERIALS AND METHODS}

\subsection{Materials}

The barley seed translation inhibitor II, was isolated as described (1) and has been used throughout the present work.

Bio-Gels P-100, P-60, P-10 and P-6 were from Bio-Rad, Richmond, CA; DFP-treated carboxypeptidase B and DPCC-treated trypsin from Sigma, St. Louis, MO; endoproteinase Lys-C from Boehringer Mannheim, Mannheim, F.R.G.; S. aureus V8 protease from Miles Laboratories, Elkhart, IN; clostripain, cyanogen bromide, hydroxylamine hydrochloride and tyramine hydrochloride from E. Merck, Darmstadt, F.R.G.; o-iodosobenzoic acid from Pierce, Rockford, IL. Carboxypeptidase Y was prepared in this laboratory. Solvents and reagents for sequencing and RP-HPLC were obtained from the same sources as earlier $(12,25$, $26,27)$. All other chemicals were analytical grade.

\subsection{Methods}

\subsubsection{Procedures for chemical cleavage of peptide bonds}

In order to ensure that the methionine residues were in the reduced state, the translation inhibitor $\left(37 \mathrm{mg} \cdot \mathrm{ml}^{-1}\right)$ was incubated at room temperature in $0.2 \mathrm{M}-\mathrm{Tris}-\mathrm{HCl} \mathrm{pH} 8.3$ containing $7 \mathrm{M}$-guanidine hydrochloride, $5 \mathrm{mM}$-EDTA and 13\% 2-mercaptoethanol. After $24 \mathrm{~h}$ the solution was dialyzed against $10 \%$ ethanol, $0.1 \%$ 2-mercaptoethanol and lyophilized (13, 27). The reduced translation inhibitor $\left(37 \mathrm{mg} \cdot \mathrm{ml}^{-1}\right)$ was treated with cyanogen bromide $\left(50 \mathrm{mg} \cdot \mathrm{ml}^{-1}\right)$ in $70 \%$ formic acid at room temperature in the dark. After $22 \mathrm{~h} 20$ volumes of water were added and the mixture was lyophilized. A hydroxylamine fragment (Hy2) (see section 3.4) and S. aureus V8 protease fragments (E1 plus E5) (see section 3.6) were subfragmented with cyanogen bromide. These fragments ( 2 and $2.5 \mathrm{mg} \cdot \mathrm{ml}^{-1}$, respectively) were reduced by 2 -mercaptoethanol $(25 \%)$ in $0.2 \mathrm{M}$-ammonium bicarbonate, lyophilized and cleaved (10 and $1.9 \mathrm{mg} \cdot \mathrm{ml}^{-1}$, respectively) as above.

Hydroxylamine cleavage of the Asn-Gly peptide bond was performed at a protein concentration of $3.8 \mathrm{mg} \cdot \mathrm{ml}^{-1}$ as described $(6,27)$. During the reaction $(4 \mathrm{~h})$ the $\mathrm{pH}$ was maintained at 9.0 by addition of lithium hydroxide. The reaction mixture was finally centrifuged and the supernatant desalted by gel filtration through Bio-Grel $P-10$ in 5\% acetic acid.

For cleavage at the C-terminus of tryptophanyl residues o-iodosobenzoic acid $\left(3.3 \mathrm{mg} \cdot \mathrm{ml}^{-1}\right)$ and tyramine hydrochloride $\left(4 \mathrm{mg} \cdot \mathrm{ml}^{-1}\right)$ were preincubated in $4 \mathrm{M}$-guanidine hydrochloride in $80 \%$ acetic acid at room temperature for $6 \mathrm{~h}$ in the dark (16). The translation inhibitor $(8.3$ $\left.\mathrm{mg} \cdot \mathrm{ml}^{-1}\right)$ was added and the incubation continued $22 \mathrm{~h}$. The reaction was stopped by gel filtration on Bio-Gel P-6 in $30 \%$ acetic acid.

\subsubsection{Procedures for enzymatic cleavage of peptide bonds}

The translation inhibitor $\left(2.7 \mathrm{mg} \cdot \mathrm{ml}^{-1}\right)$ was digested with S. aureus V8 protease $\left(0.1 \mathrm{mg} \cdot \mathrm{ml}^{-1}\right)$ in $50 \mathrm{~mm}$-ammonium acetate $\mathrm{pH} 4.0$ at $37^{\circ} \mathrm{C}$ for $18 \mathrm{~h}$ and the reaction mixture subsequently lyophilized. The cyanogen bromide fragment CB2 (see section 3.3) and the o-iodosobenzoic acid fragment $\mathrm{W} 1$ (see section 3.5 ) were dissolved ( 2 and $1 \mathrm{mg} \cdot \mathrm{ml}^{-1}$, respectively) in 25 $\mathrm{mm}$-Tris- $\mathrm{HCl} \mathrm{pH} 8.0,1 \mathrm{~mm}-E D T A$ and $5 \mathrm{M}$ urea and cleaved with endoproteinase Lys-C (40 $\left.\mu \mathrm{g} \cdot \mathrm{ml}^{-1}\right)(22)$ at $30^{\circ} \mathrm{C}$ for 1 or $8 \mathrm{~h}$, respectively. The reaction was stopped by gel filtration on Bio-Gel P-6 in 30\% acetic acid. The hydroxyl- 
amine fragment $\mathrm{Hyl}$ (see section 3.4) (1.2 $\mathrm{mg} \cdot \mathrm{ml}^{-1}$ ) was digested in $0.05 \mathrm{M}$-ammonium bicarbonate, $5 \mathrm{M}$-urea by clostripain $(23 \mu \mathrm{g}$. $\mathrm{ml}^{-1}$ ) at $37^{\circ} \mathrm{C}$ for $20 \mathrm{~h}$. Clostripain was preincubated with $50 \mathrm{~mm}$-dithiothreitol in $50 \mathrm{~mm}$-ammonium bicarbonate at room temperature for 1 h. The o-iodosobenzoic acid fragment W2 was dissolved $\left(0.47 \mathrm{mg} \cdot \mathrm{ml}^{-1}\right)$ in $50 \mathrm{~mm}$-ammonium bicarbonate, clostripain was added and the reaction was stopped by gel filtration as above. The $\mathrm{N}$-terminal cyanogen bromide fragment (CB1) (see section 3.3) $\left(0.5 \mathrm{mg} \cdot \mathrm{ml}^{-1}\right)$ was digested in 50 mM-ammonium bicarbonate $\mathrm{pH} 7.8$ by trypsin $\left(0.1 \mathrm{mg} \cdot \mathrm{ml}^{-1}\right)$ at $37^{\circ} \mathrm{C}$ for $1 \mathrm{~h}$ and lyophilized.

\subsubsection{Mass spectrometry}

Plasma desorption mass spectrometry of the underivatized peptide $\mathrm{CB} 1$ was performed on a Bio-Ion Bin 10K plasma desorption time-offlight mass spectrometer (Danish Technical Science Research Council grants Nos. 16-3595H718 and $16-3781 \mathrm{H}$ ). The sample (approx. 2 nmoles) was dissolved in $10 \mu \mathrm{l}$ acetic acid/trifluoroacetic acid $9: 1 \mathrm{v} / \mathrm{v}$, electrosprayed on a 0.5 $\mu \mathrm{m}$ thick aluminium foil and bombarded with fission fragments from a $10 \mu \mathrm{C}^{252} \mathrm{Cf}$ source. The spectra were recorded for $5 \times 10^{5}$ primary ions corresponding to approx. $8 \mathrm{~min}$. Details of the mass spectrometric procedure have been described previously (24).

Electron impact mass spectrometry of peptide CB1 was performed on a Finnigan MAT 311A mass spectrometer coupled to an SS200 data system (Danish Natural Science Research Council grants Nos. 511-3809 and 511-10046). The mass spectrometer was operated at a resolution of 1000 and $70 \mathrm{eV}$ electron energy. The sample ( 20 nmoles) was $\mathrm{N}$-trideuterioacetylated and N,O-permethylated using the procedure previously described (21). The permethylated sample was introduced via the direct inlet probe and spectra recorded during heating of the probe from 50 to $300{ }^{\circ} \mathrm{C}$ in $10 \mathrm{~min}$ using a linear temperature programme.

\subsubsection{C-terminal amino acid determination}

The translation inhibitor $\left(4 \mathrm{mg} \cdot \mathrm{ml}^{-1}\right)$ in 50 mM-N-ethylmorpholine acetate $\mathrm{pH} 8.55$ was incubated with carboxypeptidases B $(0.40$ $\left.\mathrm{mg} \cdot \mathrm{ml}^{-1}\right)$ plus $Y\left(0.31 \mathrm{mg} \cdot \mathrm{ml}^{-1}\right)$ at room temperature. Aliquots, removed after 30 and $75 \mathrm{~min}$ incubation, were added an equal volume of 0.4 $\mathrm{M}-\mathrm{HCl}$, and directly applied on the amino acid analyzer. The remaining reaction mixture was adjusted to pH 6.0 with $3 \%$ acetic acid, more carboxypeptidase $\mathrm{Y}\left(0.23 \mathrm{mg} \cdot \mathrm{ml}^{-1}\right)$ was added and the digestion continued for $15 \mathrm{~min}$. The C-terminal fragment (CB5) (see section 3.3) (0.4 $\mathrm{mg} \cdot \mathrm{ml}^{-1}$ ) in $130 \mathrm{~mm}-\mathrm{N}$-ethylmorpholine acetate pH 8.55 was digested with carboxypeptidases B $\left(0.33 \mathrm{mg} \cdot \mathrm{ml}^{-1}\right)$ plus $\mathrm{Y}\left(0.39 \mathrm{mg} \cdot \mathrm{ml}^{-1}\right)$ at room temperature for $1 \mathrm{~h}$. Released amino acids were analyzed as above.

\subsubsection{Separation of peptides}

Separation and purification of peptides was performed by gel filtration through Bio-Gel $\mathrm{P}-100, \mathrm{P}-60$ or $\mathrm{P}-10$ in $5 \%$ acetic acid. Some peptide mixtures were fractionated by RP$\operatorname{HPLC}(15,26)$ either directly or after initial desalting (see sections 2.2.1 and 2.2.2). A Waters chromatograph equipped with a Wide Pore $C_{18}$ column $(0.46 \times 25 \mathrm{~cm}$, J.T. Baker Research Products) was used for RP-HPLC and elution was performed in $0.1 \%$ trifluoroacetic acid with a linear gradient of 0 to $40 \%$ 1-propanol over 80 min at a flow rate of $0.5 \mathrm{ml} \cdot \mathrm{min}^{-1}$ where nothing else is mentioned.

\subsubsection{Amino acid sequence analysis}

Peptides were sequenced either on a Beckman model $890 \mathrm{C}$ liquid phase sequencer as previously described (12) or on an Applied Biosystems model $470 \mathrm{~A}$ gas-phase sequencer according to the manufacturers' instructions. The PTH-aminoacids were identified by HPLC (25).

\subsubsection{Analytical procedures}

Amino acid compositions were determined after $24 \mathrm{~h}$ hydrolysis as previously reported (1). Tryptophan contents were analyzed after hydrolysis with $4 \mathrm{M}$-methanesulfonic acid at $125^{\circ} \mathrm{C}$ for $20 \mathrm{~h}$. The molecular weight of a large peptide (CB2) was estimated by SDS-PAGE as described (1). 
10

20

30

40

50

AC-A AKM A KN VDKPLFTATFNVQASSADYATFIAGIRNKLRNPAHFSHNEPVL $C B 1(M S)$ $\mathrm{CB} 2$

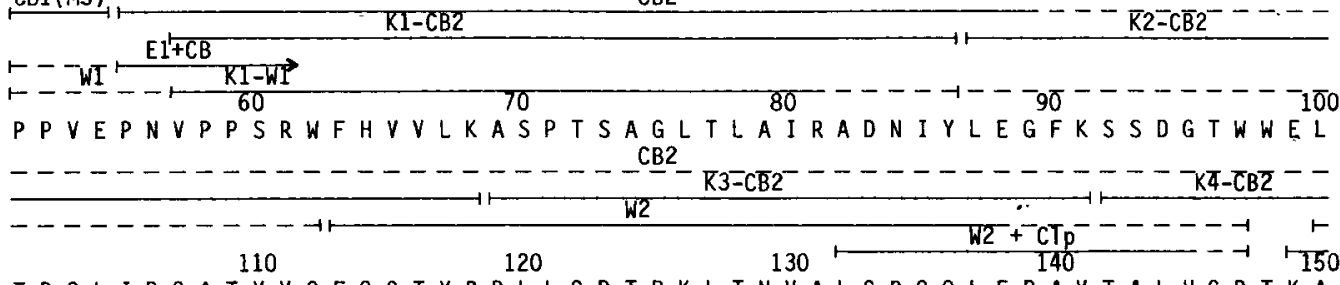

TPGLIPGATYVGFGGTYRDLLGDTDKLTNVALGRQQLEDAVTALHGRTKA

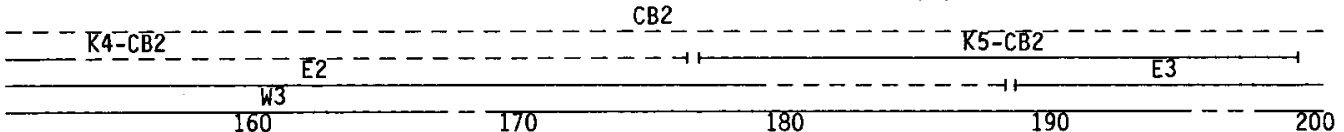

DKASGPKQQQAREAVTTLLLMVNEATRFQTVSGFVAGLLHPKAVEKKSGK

-

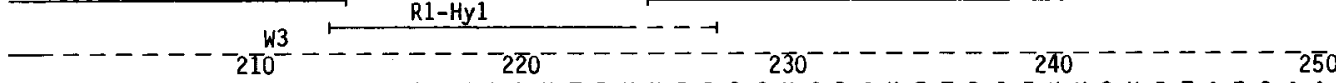

I GNEMKAQVNGWQDLSAALLKTDVKPPPGKSPAKFTPIEKMGVRTAEQAA

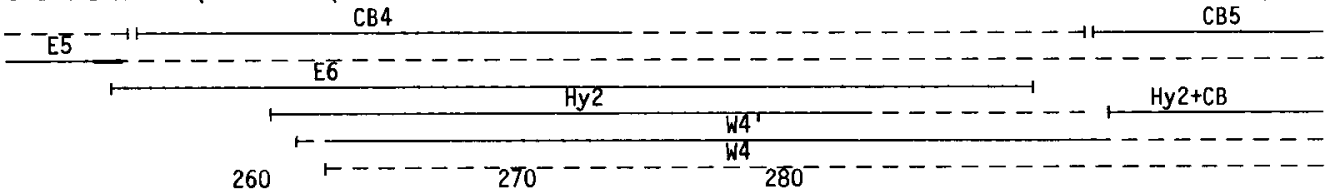

A TLGILLFVEVPGGLTVAKALELFHASGGK

CB5

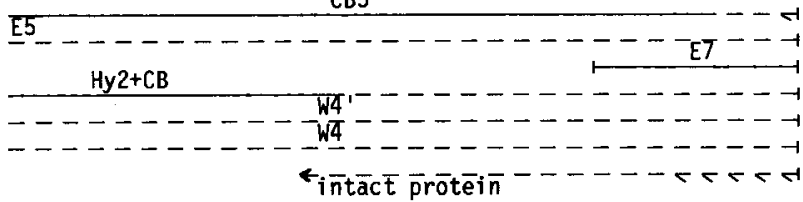

Figure 1. The complete amino acid sequence of the barley translation inhibitor II. Peptides were sequenced by either automated Edman degradation (-), digestion with carboxypeptidases B and $Y(-)$ or mass spectrometry ( $\stackrel{\text { MS }}{-}$. The total size of a peptide fragment is indicated by a full line followed by a broken line under residues which were not sequenced in that particular fragment. Peptide fragments are designated by the following nomenclature: $\mathrm{CB}$, cyanogen bromide fragments; $\mathrm{Hy}$, hydroxylamine fragments; $\mathrm{W}$, o-iodosobenzoic acid fragments; $\mathrm{E}, \mathrm{S}$. aureus V8 protease fragments; $\mathrm{K}$, endopeptidase Lys-C fragments; $\mathbf{R}$, clostripain fragment. Clp = clostripain.

\subsubsection{Peptide nomenclature}

Fragments obtained by cleavage with cyanogen bromide, hydroxylamine, o-iodosobenzoic acid, and $\mathrm{S}$. aureus V8 protease are designated $\mathrm{CB}, \mathrm{Hy}, \mathrm{W}$, and $\mathrm{E}$, respectively, followed by a number indicating their position in the polypeptide chain from the $\mathrm{N}$-terminus of the protein. Secondary fragments generated by digestion with endoproteinase Lys-C or clostripain are named $K$ and $R$, respectively, and numbered according to their position in the corresponding primary fragments.

\section{RESULTS AND DISCUSSION}

\subsection{N-terminal sequence}

The translation inhibitor has a blocked $\mathrm{N}$-terminus (1). The N-terminal cyanogen bromide fragment (CB1) (see section 3.3) contained two alanyl, one lysyl and one homoseryl residues 
Table I. Amino acid composition of cyanogen bromide fragments

\begin{tabular}{|c|c|c|c|c|c|c|c|c|c|c|c|c|}
\hline \multirow{3}{*}{$\begin{array}{l}\text { Amino acid } \\
\text { Aspartic acid }\end{array}$} & \multicolumn{12}{|c|}{ Residues per fragment or molecule } \\
\hline & \multicolumn{2}{|c|}{ CB1 } & \multicolumn{2}{|c|}{ CB2 } & \multicolumn{2}{|c|}{ CB3 } & \multicolumn{2}{|c|}{ CB4 } & \multicolumn{2}{|c|}{ CB5 } & \multicolumn{2}{|c|}{$\begin{array}{l}\text { Translation } \\
\text { inhibitor }\end{array}$} \\
\hline & & $(0)$ & $\left.\begin{array}{l}9 \\
8\end{array}\right\}$ & $(15.9)$ & $\begin{array}{l}0 \\
2\end{array}$ & $(2.0)$ & $\begin{array}{l}2 \\
1\end{array}$ & $(3.0)$ & $\begin{array}{l}0 \\
0\end{array}$ & $(0.2)$ & 22 & $(22)$ \\
\hline Threonine & 0 & $(0)$ & 15 & $(13.9)$ & 2 & (1.9) & 2 & $(2.0)$ & 3 & (2.9) & 21 & $(21)$ \\
\hline Serine & 0 & $(0)$ & 9 & $(8.5)$ & 2 & (1.9) & 2 & $(1.8)$ & 1 & $(1.0)$ & 14 & (14) \\
\hline $\begin{array}{l}\text { Glutamic acid } \\
\text { Glutamine }\end{array}$ & $\begin{array}{l}0 \\
0\end{array}$ & $(0)$ & $\left.\begin{array}{l}6 \\
6\end{array}\right)$ & $(12.0)$ & $\begin{array}{l}3 \\
1\end{array}$ & $(4.0)$ & $\begin{array}{l}1 \\
2\end{array}$ & $(3.2)$ & $\begin{array}{l}3 \\
1\end{array}$ & $(3.9)$ & 23 & (22) \\
\hline Proline & 0 & (0) & 12 & $(11.2)$ & 1 & $(0.9)$ & 5 & $(5.0)$ & 1 & $(1.0)$ & 19 & (18) \\
\hline Glycine & 0 & $(0)$ & 13 & $(13.0)$ & 4 & $(4.0)$ & 2 & (2.1) & 6 & $(5.8)$ & 25 & (25) \\
\hline Alanine & 2 & $(2.0)$ & 19 & $(19.3)$ & 3 & (3.0) & 4 & $(4.3)$ & 7 & $(6.8)$ & 35 & (34) \\
\hline Valine & 0 & $(0)$ & 11 & $(10.3)$ & 4 & (3.9) & 2 & $(1.9)$ & 4 & (3.8) & 21 & $(20)$ \\
\hline Methionine & - & & - & & - & & - & & - & & 4 & $(3.7)$ \\
\hline Isoleucine & 0 & (0) & 5 & $(3.9)$ & 1 & $(1.0)$ & 1 & $(1.0)$ & 1 & (1.0) & 8 & $(7.0)$ \\
\hline Leucine & 0 & $(0)$ & 18 & (18.3) & 2 & $(2.2)$ & 3 & (3.2) & 6 & $(6.0)$ & 29 & $(28)$ \\
\hline Tyrosine & 0 & $(0)$ & 4 & $(4.0)$ & 0 & $(0.0)$ & 0 & $(0.0)$ & 0 & $(0.0)$ & 4 & $(3.8)$ \\
\hline Phenylalanine & 0 & $(0)$ & 7 & $(7.4)$ & 2 & $(2.1)$ & 1 & $(1.0)$ & 2 & (1.8) & 12 & $(12)$ \\
\hline Histidine & 0 & $(0)$ & 4 & (3.7) & 1 & $(1.0)$ & 0 & $(0.0)$ & 1 & $(1.0)$ & 6 & (6) \\
\hline Lysine & 1 & $(0.9)$ & 9 & $(9.4)$ & 4 & (3.8) & 6 & $(5.9)$ & 2 & (1.9) & 22 & (22) \\
\hline Arginine & 0 & $(0)$ & 8 & $(8.4)$ & 1 & (1.0) & 0 & $(0.0)$ & 1 & $(1.0)$ & 11 & (11) \\
\hline Tryptophan & 0 & $(-)$ & 3 & $(2.8)$ & 0 & $(0.9)$ & 1 & $(1.0)$ & 0 & $(0.0)$ & 4 & (4) \\
\hline \multirow{2}{*}{$\begin{array}{l}\text { Homoserine }+ \\
\text { Homoserine lactone }\end{array}$} & 1 & $(1.0)$ & 1 & $(1.0)$ & 1 & $(1.0)$ & 1 & $(1.0)$ & - & & & \\
\hline & 4 & & 167 & & 34 & & 36 & & 39 & & 280 & \\
\hline
\end{tabular}

The values in parenthesis were determined by amino acid analysis and have not been corrected for destruction or incomplete hydrolysis.

(Figure 1, Table I). No PTH-amino acid was released when $\mathrm{CB} 1$ was subjected to sequencing after incubation with trypsin in accordance with the tentative structure: blocked-Ala-Ala-LysHse. The peptide was therefore analyzed by mass spectrometry.

The plasma desorption mass spectrum of underivatized CB1 (Figure 2) contained a single major peak at $\mathrm{m} / \mathrm{z} 436.6$, accompanied by less abundant peaks at 452.8 and 458.6 . The mass differences between these peaks are characteristic for the series of cationized molecular ions $\mathrm{MNa}^{+}, \mathrm{MK}^{+}$, and $(\mathrm{M}-\mathrm{H}+2 \mathrm{Na})^{+}$resulting in a measured molecular weight for $\mathrm{CB} 1$ of $413.6 \pm$ 0.1 . Considering the amino acid composition of CB1 (Table I) and assuming C-terminal homoserine lactone, this molecular weight shows a blocking group of mass 43 indicative of an acetyl group.

The plasma desorption spectrum did not contain sufficient fragment ions to assign the sequence of $C B 1$. A new preparation of the peptide was therefore $\mathrm{N}$-deuterioacetylated in order to allow a distinction between already existing acetyl groups and acetyl groups introduced during the derivatization reactions, and then N,Opermethylated. The mass spectrum (Figure 3) shows an $\mathrm{N}$-terminal acetylated alanyl residue indicated by peaks at $\mathrm{m} / \mathrm{z} 100$ and 128 . This acetyl group is not deuteriated proving that $\mathrm{CB} 1$ was $\mathrm{N}$-acetylated. The sequence of the peptide is Ac-Ala-Ala-Lys-Hse indicated by peaks at $\mathrm{m} / \mathrm{z}$ $100,128,213,386,414$, and 543 and a molecular ion at 574 . The lactone ring of the C-ter- 


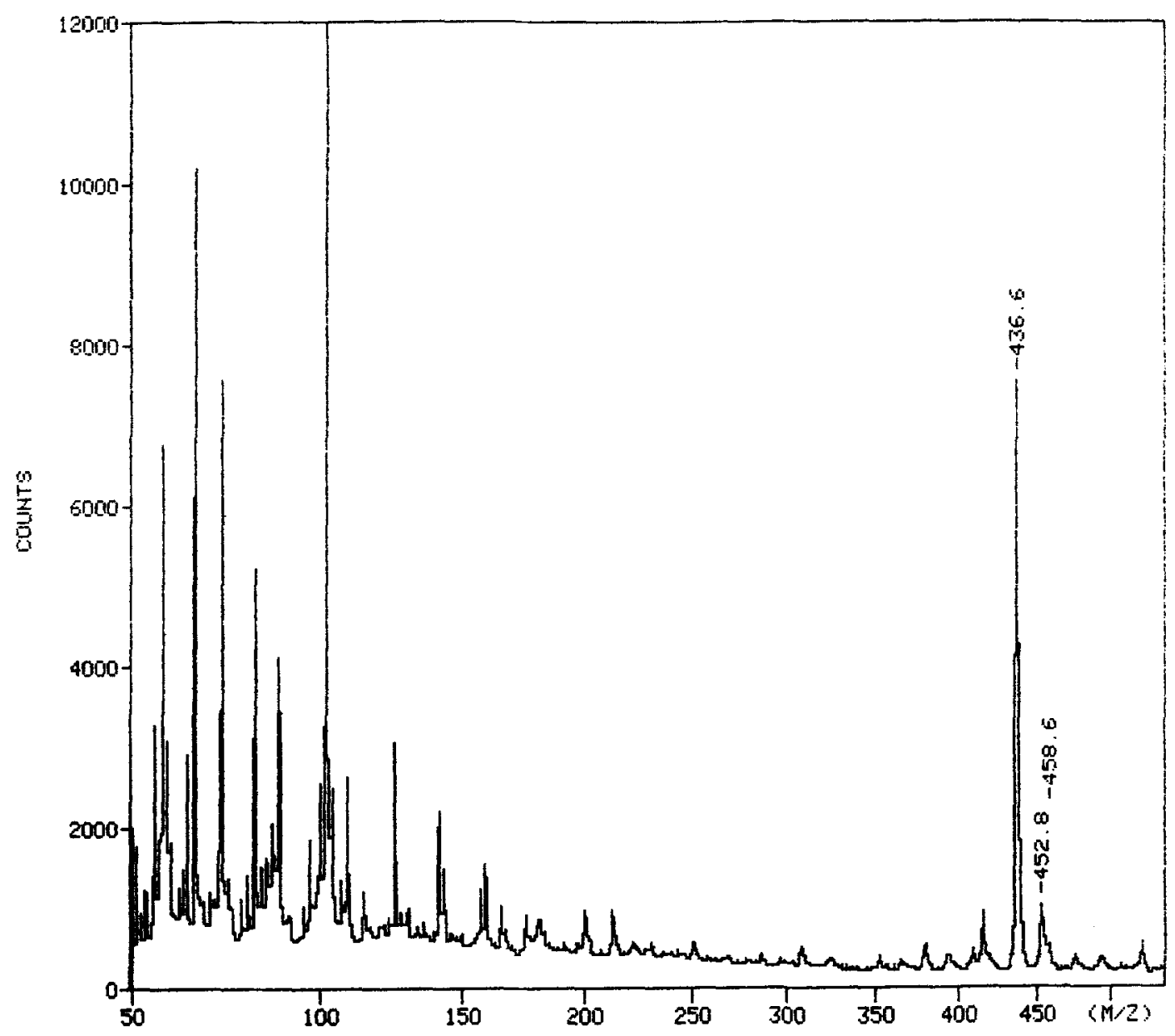

Figure 2. Plasma desorption mass spectrum of peptide CB1.

minal homoserine lactone is opened during the permethylation reaction. Peaks at $\mathrm{m} / \mathrm{z} 383,411$, 540 , and 571 , i.e. three mass units below the above-mentioned sequence might indicate that the \&-amino group of Lys-3 was partially acetylated in this preparation of the peptide. This phenomenon will be subject to further investigation.

\subsection{C-terminal sequence}

In order to identify the C-terminus, the translation inhibitor was digested with carboxypeptidases $B$ and $Y$ in combination. Lysine, two glycines, serine and alanine were released in that order and 0.7 lysine per peptide was released from the C-terminal fragment CB5 (see section 3.3) identified by its lack of homoserine (Table I). These results suggested the C-terminal sequence to be -Ala-Ser-Gly-Gly-Lys as later confirmed by gas-phase sequencing of another Cterminal fragment prepared using $\mathrm{S}$. aureus V8 protease (E7, see section 3.6).

\subsection{Cyanogen bromide fragments}

The translation inhibitor contains four methionine residues and cleavage with cyanogen bromide followed by sequencing of the resulting peptide mixture demonstrated accordingly four new N-termini. The fragments were separated by gel filtration through Bio Gel P-60 (Figure 4) 


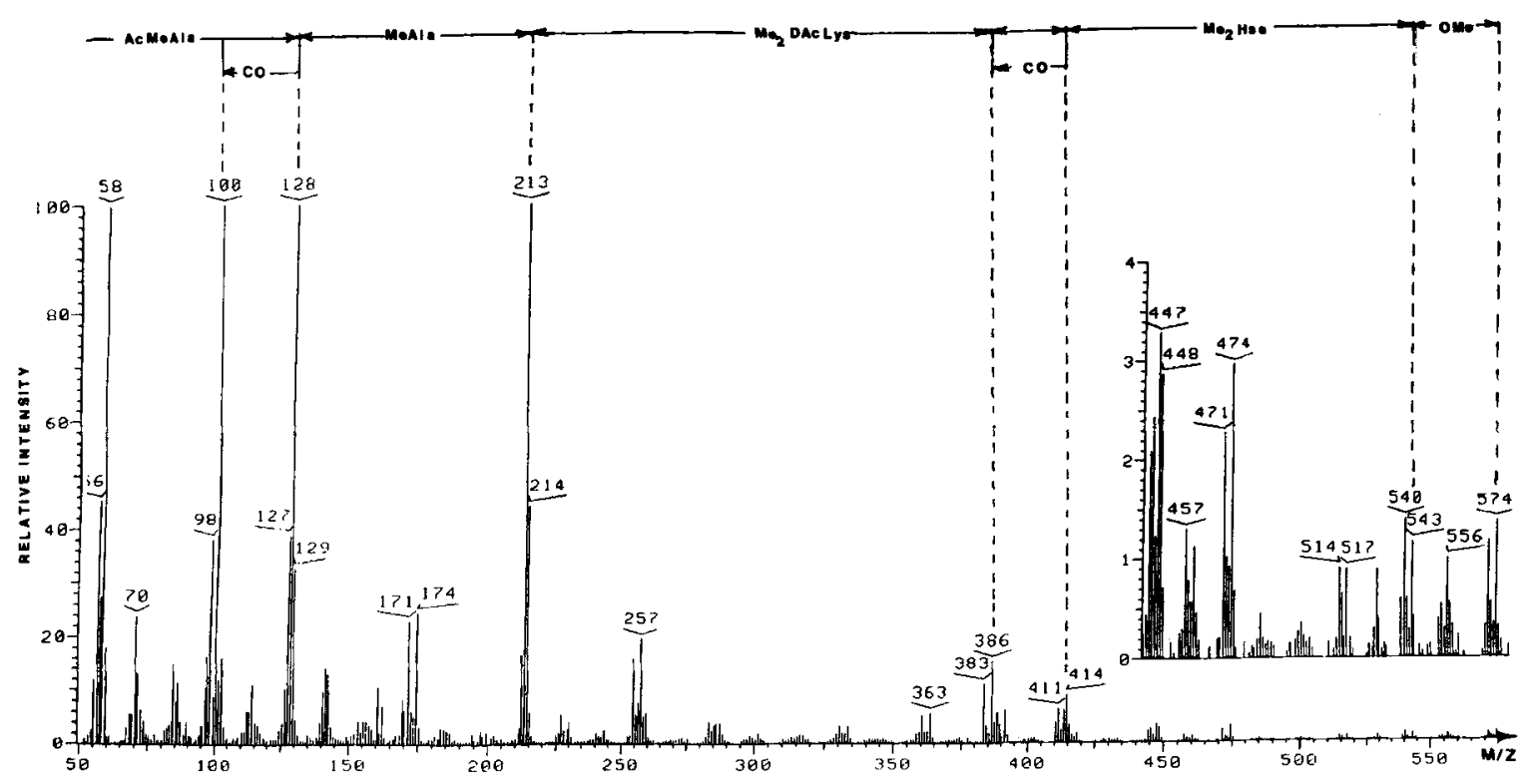

Figure 3. Electron impact mass spectrum of the $\mathrm{N}$-trideuterioacetylated and $\mathrm{N}, \mathrm{O}$-permethylated derivative of peptide CB1.

and further purified by RP-HPLC. From pool 1 was obtained a single fragment Ala(5)-Hse(171) (CB2, Figure 1) of apparent $M_{r} 20,000$ (determined by SDS-PAGE, not shown). Three fragments Lys(206)-Hse(241) (CB4), Val(172)Hse(205) (CB3), and Gly(242)-Lys(280) (CB5), respectively, were purified from pool 2 (Figure 5). Pool 3 contained the N-terminal peptide Ac-Ala(1)-Hse(4) (CB1) (see section 3.1), its elution position in RP-HPLC is indicated in Figure 5. The finding of four methionyl residues by amino acid analysis of translation inhibitor II and the excellent agreement of the composition of the five fragments CB1-CB5 with that of the intact protein (Table I) allowed the alignment of CB1 and CB2 despite the lack of an overlapping fragment.

The $35 \mathrm{~N}$-terminal residues of the large fragment CB2 (Table I) were identified by automated sequencing (Figure 1). Subfragmentation of $\mathrm{CB} 2$ with endoproteinase Lys-C, and subsequent purification by RP-HPLC (Figure 6) led to isolation of five fragments. The complete sequences of four of these, K5-CB2, K2-CB2, $\mathrm{K} 1-\mathrm{CB} 2, \mathrm{~K} 3-\mathrm{CB} 2$, and the partial sequence for $\mathrm{K} 4-\mathrm{CB} 2$ were determined by gas-phase sequenc-

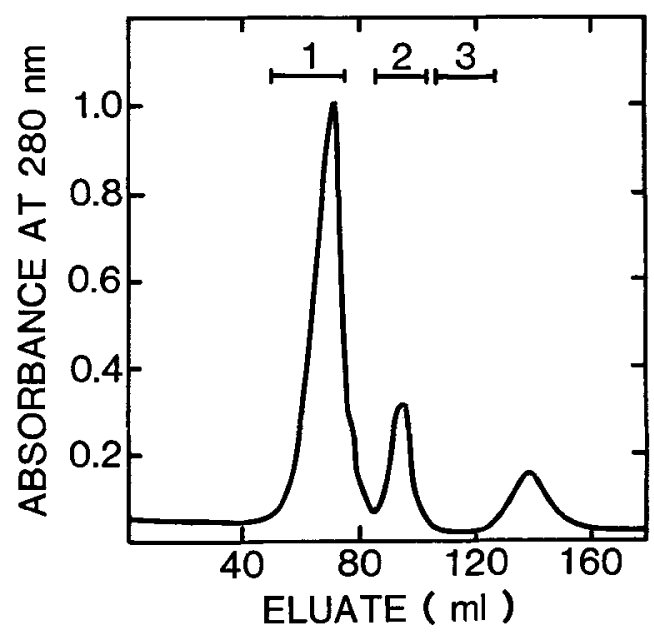

Figure 4. Separation of cyanogen bromide fragments $(37 \mathrm{mg})$ on Bio-Gel P-60. The column $(1.5 \times 90 \mathrm{~cm})$ was eluted with $5 \%$ acetic acid at a flow rate of $8 \mathrm{ml} \cdot \mathrm{h}^{-1}$. The eluate was monitored for the absorbance at 280 $\mathrm{nm}$ and pooled as indicated. The pools 1, 2 (Figure 5) and 3 were further purified by RP-HPLC. 


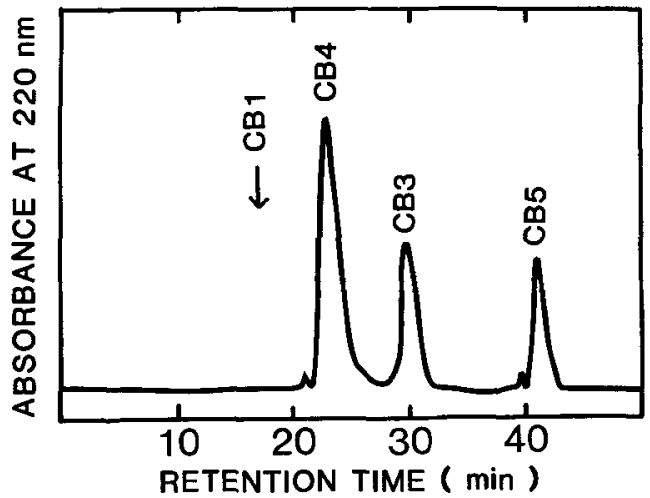

Figure 5. Further separation of cyanogen bromide fragments in pool 2 (10.9 mg, Figure 4) by RP-HPLC on a Wide Pore $C_{18}$ column. The sample was purified in portions of $3.6 \mathrm{mg}$, the column being eluted over 50 min applying a linear gradient of 16 to $40 \% 1$-propanol in $0.1 \%$ trifluoroacetic acid at a flow rate of 0.5 $\mathrm{ml} \cdot \mathrm{min}^{-1}$. The eluate was monitored for absorbance at $220 \mathrm{~nm}$.

ing (Figure 1). The Lys(10)-Pro(11) bond (Figure 1) apparently has not been cleaved by endoproteinase Lys- $\mathrm{C}$. The order of these fragments in the primary structure was established by aid of the o-iodosobenzoic acid fragments Phe(63)-Trp(97) (W2) and Glu(99)-Lys(280) (W3 + W4), (Figure 1, see section 3.5). An

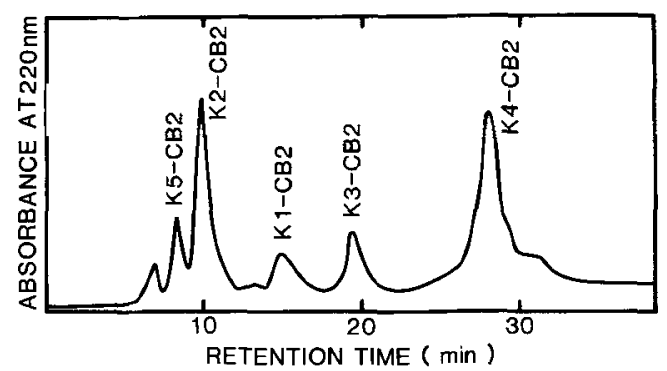

Figure 6. Separation of endoproteinase Lys-C fragments from CB2 $(1 \mathrm{mg})$ by RP-HPLC on a Wide Pore $\mathrm{C}_{18}$ column. The column was eluted over $40 \mathrm{~min}$ applying a gradient of 21 to $40 \%$ 1-propanol in $0.1 \%$ trifluoroacetic acid at a flow rate of $0.5 \mathrm{ml} \cdot \mathrm{min}^{-1}$. The eluate was monitored for the absorbance at $220 \mathrm{~nm}$.

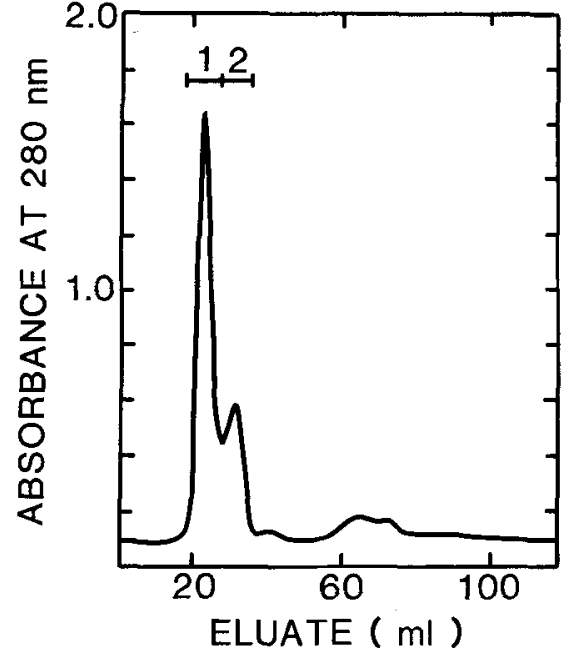

Figure 7. Separation of hydroxylamine fragments (19 $\mathrm{mg}$ ) on Bio-Gel P-10. The column $(1.5 \times 35 \mathrm{~cm})$ was eluted with $5 \%$ acetic acid at a flow rate of $7.4 \mathrm{ml} \cdot \mathrm{h}^{-1}$. Material in the indicated pools was further purified by gel filtration through Bio-Gel P-60.

overlapping fragment verifying the positions of $\mathrm{K} 3-\mathrm{CB} 2$ and $\mathrm{K} 4-\mathrm{CB} 2$ was generated from $\mathrm{W} 2$ by clostripain (Figure 1). The additional fragments R1-Hyl (see section 3.4) and E3 (see section 3.6) enabled completion of the total sequence of CB2.

\subsection{Hydroxylamine fragments}

An Asn-Gly sequence was found in CB4, and treatment of the intact translation inhibitor with hydroxylamine actually resulted in two fragments isolated by gel filtration through Bio-Gel P-10 (Figure 7) and subsequently purified on Bio-Gel P-60. Pool 1 contained the N-terminal Ac-Ala(1)-Asn (210)(Hy1), while the C-terminal fragment Gly(211)-Lys(280) (Hy2) eluted in pool 2. The N-terminal sequence of CB5 appeared upon cleavage of $\mathrm{Hy} 2$ with cyanogen bromide proving the location of CB4 in the primary structure (Figure 1). Clostripain digestion of $\mathrm{Hyl}$ followed by RP-HPLC yielded among other fragments Glu(163)-Arg(177) (R1Hy1) which joined CB2 and CB3 together (Figure 1). 


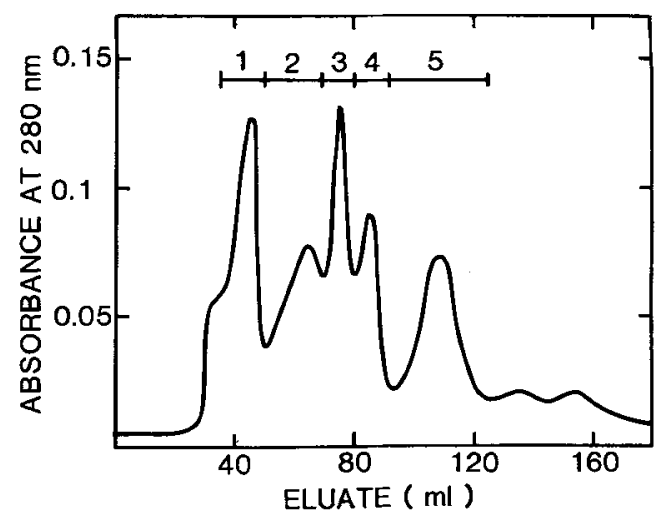

Figure 8. Separation of o-iodosobenzoic acid fragments (19 mg) on Bio-Gel P-60. The elution condition was the same as in Figure 4. The eluate was pooled as indicated.

\section{5. o-Iodosobenzoic acid fragments}

The translation inhibitor was treated with o-iodosobenzoic acid to obtain cleavage at the C-terminus of tryptophanyl residues (16). The resulting fragments were separated by gel filtration through Bio-Gel P-60 (Figure 8) and further purified on either Bio-Gel P-100, P-60 or P-10. The pools 2 and 5 contained the incompletely cleaved Glu(99)-Lys(280) (W3+W4) and Phe(63)-Trp(97) (W2), respectively (Figure 1). Pool 1 contained (W3+W4) in addition to a fragment Trp(212)-Lys(280) (W4') which apparently was generated by the exceptional cleavage of a Gly-Trp sequence. The latter fragment was identified by sequencing but no corresponding PTH-amino acid appeared in the first cycle (Figure 1). A fragment purified from pool 4 was N-terminally blocked and Asn(7)-Lys(36) (K1W1) recognized in CB2 (Figure 1) was obtained by treatment with endoproteinase Lys-C imply-

Table II. Amino acid composition of o-iodosobenzoic acid fragments

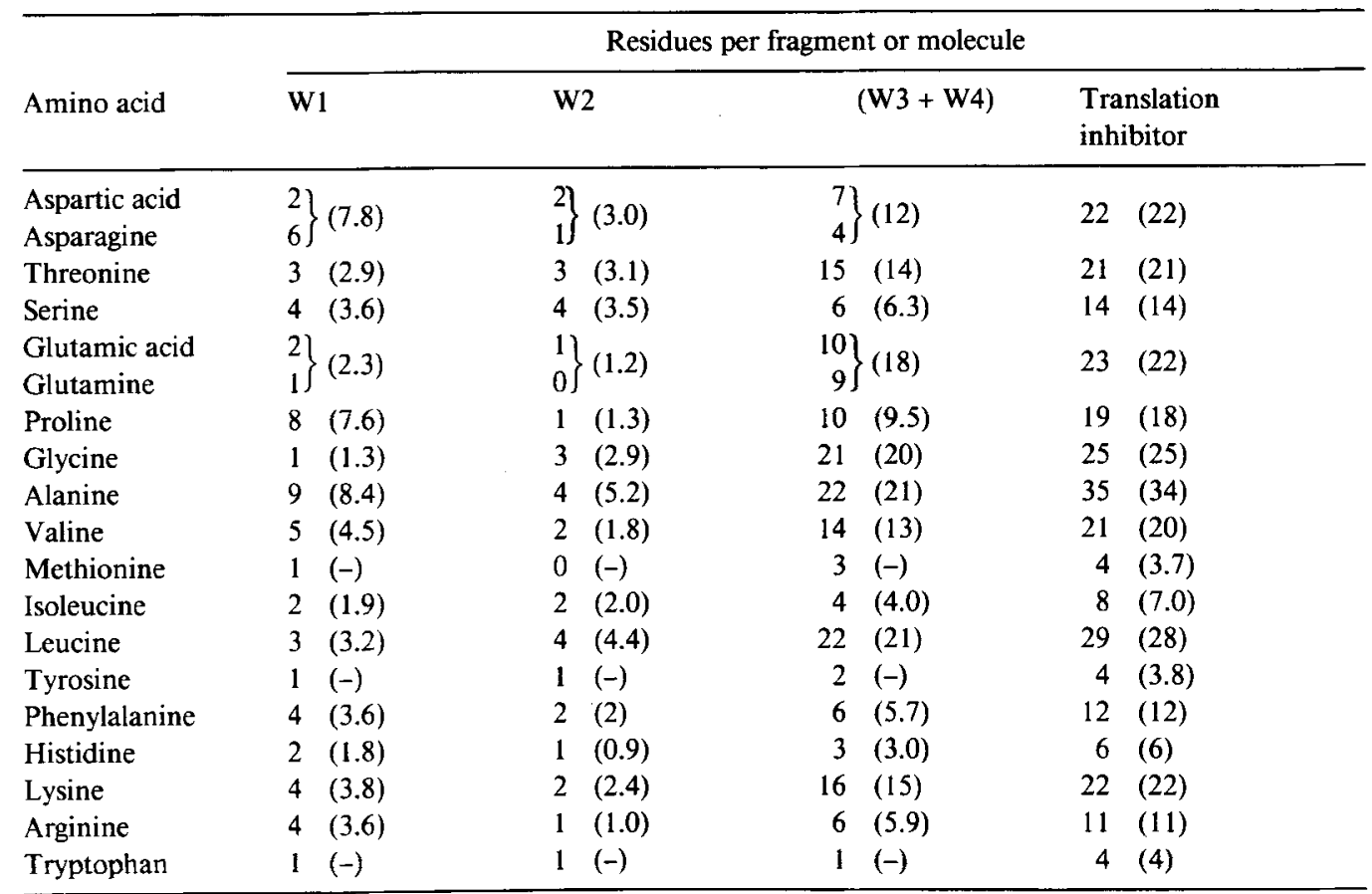

The values in parenthesis were determined by amino acid analysis and have not been corrected for destruction or incomplete hydrolysis. 


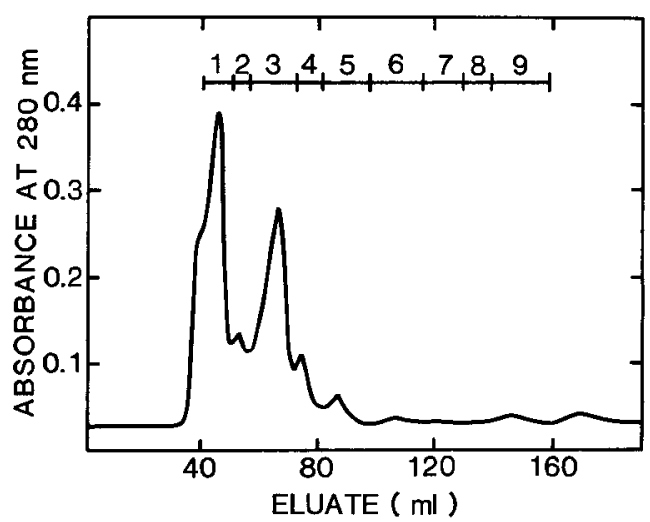

Figure 9. Separation of S. aureus V8 protease fragments $(26 \mathrm{mg}$ ) on Bio-Gel P-60. The elution condition was the same as in Figure 4. The eluate was pooled as indicated.

ing the primary fragment to be the $\mathrm{N}$-terminal Ac-Ala(1)-Trp(62) (W1). Another N-terminally blocked peptide was isolated from pool 3. Its amino acid composition (data not shown) matched the sequence Gln(213)-Lys(280) (W4) (Figure 1). The N-terminal glutamine thus probably had cyclized yielding a pyroglutamic acid residue (5). The amino acid contents of the three peptide fragments, W1, W2, and (W3+W4) agree with that of the intact translation inhibitor II (Table II).

\subsection{S. aureus $\mathrm{V} 8$ protease fragments}

The translation inhibitor was digested with $\mathrm{S}$. aureus V8 protease. The resulting fragments were initially separated by gel filtration through Bio-Gel P-60 (Figure 9) and further purified either by RP-HPLC or gel filtration. Leu(100)Glu(138) (E2) and Asp(139)-Glu(163) (E3) were purified by RP-HPLC of pool 6. Leu(273)Lys(280) (E7) which was free from glutamic acid, was purified from pool 8 by RP-HPLC. Its complete sequence was determined which confirmed the C-terminal sequence of the protein suggested above (section 3.2). An incompletely cleaved fragment, E5, starting by Ala- 175 was identified in pool 3 and sequenced up to Met205 (Figure 1). Cleavage of material from this pool with cyanogen bromide and sequencing revealed the $\mathrm{N}$-terminal sequences of $\mathrm{CB} 2, \mathrm{CB} 4$, and $C B 5$ which suggested the presence of both Ala(175)-Lys(280) (E5) and the N-terminal fragment (E1). Met(205)-Glu(239) (E6) was obtained among other fragments by RP-HPLC of pool 5.

\subsection{Comparison with primary structures of other translation inhibitors}

The amino acid sequence of the barley translation inhibitor Il was compared with the sequence of the ricin $\mathrm{A}$-chain and the $\mathrm{N}$-terminal sequences of six other translation inhibitors from higher plants using the computer programme Relate (7). The proteins compared and the result of the analysis are listed in Table III where the segment comparison scores in standard deviation units are shown. Concerning the barley translation inhibitor the best homology as expressed in the sequence comparison score of 7.881 S.D. units, was calculated for the ricin

Table III. Relationship between barley translation inhibitor II and other translation inhibitors from higher plants

\begin{tabular}{ccccccccc}
\hline \multicolumn{10}{c}{ Segment comparison score in S.D. units } \\
\hline \multirow{3}{*}{ BPSI } & BPSI & RICA & PAP2 & PAP & PAPS & DODE & SO-6 & MODA \\
\hline & 0.626 & 7.881 & 0.508 & 1.386 & 0.212 & 2.097 & 2.920 & -0.269 \\
\hline
\end{tabular}

Results of the homology analysis using the Relate programme presented as the segment comparison scores in standard deviation units (S.D.). The analysis was performed using the Mutation Data Matrix (7) as a scoring matrix. Fragments, 35 residues long, were compared and the statistic analysis was based on scores obtained from 100 randomized sequence comparisons. The $\mathrm{N}$-terminal sequences of PAP (11), dodecandrin (18), SO-6 (14), PAP2 and PAPS (4), modeccin A-chain (19), and the complete sequences of ricin A-chain (9) and barley translation inhibitor II (the present study) are included in the analysis. 


\section{$\begin{array}{llllll}1 & 5 & 10 & 15 & 20 & 25\end{array}$}

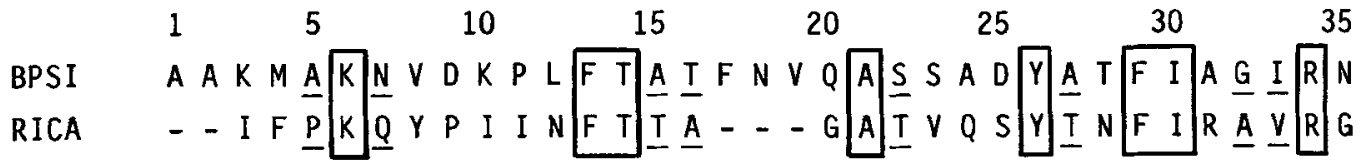
40
$45 \quad 50 \quad 55$
60
65
70

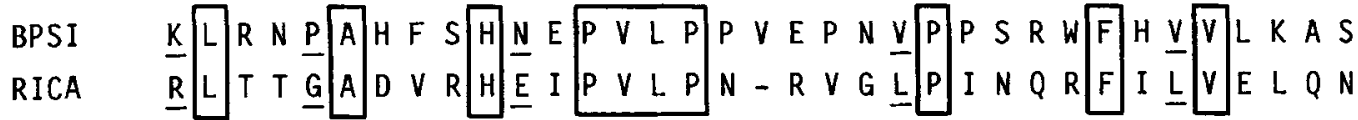

$\begin{array}{lllllll}75 & 80 & 85 & 90 & 95 & 100 & 105\end{array}$

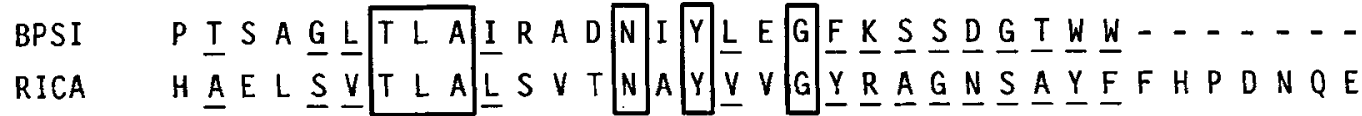
$\begin{array}{lllllll}110 & 115 & 120 & 125 & 130 & 135 & 140\end{array}$

BPSI - ..... E E L RICA DAEA I T HLLF I D $\underline{V} Q$ Q N R Y T F - A F G G N Y D RLLE Q L A G NLL $\begin{array}{lllllll}145 & 150 & 155 & 160 & 165 & 170 & 175\end{array}$

BPSI - T N RICA RE N I ELL G G PLEEEA] I S A L Y - . Y Y Y S I G G I Q L P T L $\begin{array}{lllllll}180 & 185 & 190 & 195 & 200 & 205 & 210\end{array}$

BPSI RE RICA A R $\underline{S}$ F I I C I Q M I SE A A R F Q - - - Y I E G E M R I R I R Y N

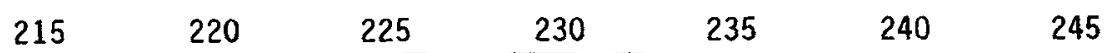

BPSI KS GKIGNEMKA QVNGWOD L S A A L L K I D VKPPPGKS

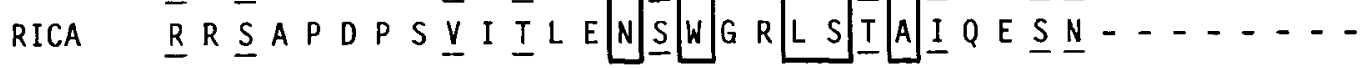
$\begin{array}{lllllll}250 & 255 & 260 & 265 & 270 & 275 & 280\end{array}$

BPSI P AKKFI P I EKMGVRIIE Q A A A T L G I L LF VEVPGGLT RICA Q $\underline{G} A$ F $\underline{A} \underline{S} P$ I $Q \underline{L} Q R D \underline{G} S K F \underline{S} V Y D \underline{V} \underline{S} I L L P I I A M V Y R C$ $285290 \quad 295$

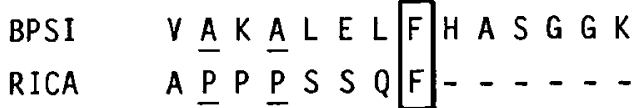

Figure 10. Alignment of the sequences of the barley translation inhibitor and the ricin A-chain. The alignment was performed by the computer programme Align (7)employing the Mutation Data Matrix and a penalty score of twelve for breaks. Positions with identical residues are boxed and those positions where conservative substitutions appear to have occurred are underlined. The definition of conservative substitutions was based on the classification of the amino acids in subgroups as described by DAYHOFF et al. (8). These groups are: C; I, L, M, and V; D, E, N, and Q; $\mathrm{H}, \mathrm{K}$, and $\mathrm{R} ; \mathrm{A}, \mathrm{G}, \mathrm{P}, \mathrm{S}$, and $\mathrm{T} ; \mathrm{F}, \mathrm{W}$, and $\mathrm{Y}$.

A-chain (9). Similar homology was noted between the barley inhibitor and the $\mathrm{N}$-terminal sequences of the SO- 6 protein (14) and dodecan- drin (18) for which the scores are 2.920 and 2.097 S.D. units, respectively. Homologies between the barley protein and N-terminal se- 


\begin{tabular}{|c|c|}
\hline ICA & YPIINFTTA \\
\hline 3PSI & LF TAT $\underline{F} \mathbb{N} \vee Q A \underline{S} \underline{S} A D-\underline{Y} A \underline{T} \underline{F} \underline{I}$ A G I $\underline{R} \underline{N} K L \underline{R} \underline{N} \underline{P} A H F S H N E \underline{P} V \underline{L}$ \\
\hline DDA & $F P K \underline{V} T L \underline{D} D T R$. \\
\hline DODE & 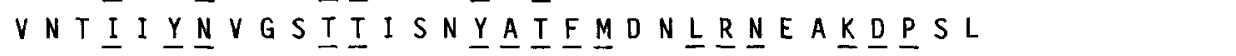 \\
\hline PAP2 & $-N \underline{I} V \underline{F} \underline{D} \vee E N \underline{A} \underline{T} P E T \underline{Y} \underline{S} N \underline{F} \underline{L} T S \underline{L} \underline{R} \underline{E} A \vee \underline{K} \underline{D} K K L T$ \\
\hline AP & $\vee N T I I \underline{Y} \underline{N} \vee G S I I$ I $S K \underline{Y} \underline{A} I \underline{T} \underline{L} N D \underline{L} R \underline{N} E A \underline{K} \underline{D} \cdots-\cdots S \underline{L}$ \\
\hline$A P$ & $\underline{M} F S \underline{L} X \underline{N} E A \underline{K} \underline{D}$ \\
\hline $0-$ & $V K I \underline{R} N N \underline{K} \underline{D} \underline{P} N K$ N Y G S T \\
\hline
\end{tabular}

Figure 11. Alignment of the N-terminals of PAP, dodecandrin, SO-6, PAP2, PAPS, and modeccin A-chain with the homologous segments of the ricin A-chain (residues 6-45, the numbering indicated), and the barley translation inhibitor (residues 12-50). The residues are marked as described above, however, only when in $3 / 4$ of the sequences compared conservative substitutions are found in a given position, this is underlined.

quences of the remaining four proteins $(4,11$, 19) was further examined using the computer programme Align (7) to compare the regions that the Relate programme had identified as homologous. The result of the alignment analysis is shown in Figure 10 where the complete sequences of the ricin A-chain and the barley translation inhibitor are aligned, and in Figure 11 , where the $\mathrm{N}$-terminal sequences of the six related proteins are compared to the segment 12-50 of the barley inhibitor and to the segment 6-45 of the ricin A-chain.

\section{CONCLUSION}

In summarizing, the barley translation inhibitor II is the first single polypeptide chain translation inhibitor from higher plants to be sequenced. It consists of 280 amino acid residues and the molecular weight was calculated from the amino acid composition to be 29836 . The $\mathrm{N}$-terminal residue acetyl-alanine was identified by mass spectrometry. A blocked $\mathrm{N}$-terminus has not been reported for other translation inhibitors from plants. The barley inhibitor shows sequence homology with the A-chain of the heterodimeric cytotoxin ricin and distant homology was also seen with partial N-terminal amino acid sequences of translation inhibitors from other unrelated plants, lending additional support to the suggestion made earlier that these proteins are of common genetic origin. A physiological role of the translation inhibitors from higher plants has not yet been clarified. However, the present barley inhibitor was recently reported to possess antifungal activity (20) suggesting that it together with inhibitors of proteases and carbohydrases constitute part of the plant defense systèm.

\section{ACKNOWLEDGEMENTS}

We are grateful to Professor MARTIN OTTESEN for his continuous encouragement and advice during this work and for his critical revision of the manuscript. Mss. BODIL CORNELiUssen, Lone Sørensen, Pia Breddam, EDITH FløISTRUP and SUSSI DOHN are acknowledged for excellent technical assistance. $\mathrm{K}$. ASANO is on leave from Kirin Brewery Co., Ltd., Tokyo, Japan and acknowledges their financial support.

\section{REFERENCES}

1. Asano, K., B. Svensson \& F. M. Poulsen: Isolation and characterization of inhibitors of animal cell-free protein synthesis from barley seeds. Carlsberg Res. Commun. 49, 619-626 (1984)

2. Asano, K., B. Svensson, F. M. Poulsen, O. NYGÁRD \& L. NILSSON: Influence of a protein synthesis inhibitor from barley seeds upon different steps of animal cell-free protein synthesis. Carlsberg Res. Commun. 51, 75-81 (1986) 
3. BARBIERI, L \& F. STIRPE: Ribosome-inactivating proteins from plants: Properties and possible use. Cancer Surveys 1, 489-520 (1982)

4. BJorn, M. J., J. LarRick, M. Piatak \& K. J. WiLSON: Characterization of translational inhibitors from Phytolacca americana. Amino-terminal sequence determination and antibody-inhibitor conjungates. Biochim. Biophys. Acta 790, 154-163 (1984)

5. ВцOMBÄCK, B.: Derivatives of glutamine in peptides. Meth. Enzymol. 11, 398-411 (1967)

6. Bornstein, P. \& G. Balian: Cleavage at Asn-Gly bonds with hydroxylamine. Meth. Enzymol. 47, 132-145 (1977)

7. Dayhoff, M. O., W. C. Barker \& L. T. Hunt: Establishing homologies in protein sequences. Meth. Enzymol 91, 524-545 (1983)

8. Dayhoff, M. O., R. M. Schwartz \& B. L. ORCOTT: In: Dayhoff, M. O. (ed. ) Atlas of Protein Sequence and Structure, National Biomedical Research Foundation, Washington, DC, Vol. 5, Suppl. 3, 345-352 (1978)

9. Funatsu, G., S. Yoshitake \& M. Funatsu: Primary structure of lie chain of ricin D. Agric. Biol. Chem. 42, 501-503 (1978)

10. Funatsu, G., M. Kimura \& M. Funatsu: Primary structure of Ala chain of ricin D. Agric. Biol. Chem. 43, 222!-2224 (1979)

11. Houston, L. L., S. Ramakrishnan \& M. A. HerMODSON: Seasonal variations in different forms of pokeweed antiviral protein, a potent inactivator of ribosomes. J. Biol. Chem. 258, 9601 -9604 (1983)

12. Johansen, J. T., C. Overballe-Petersen, B. Martin, V. Hasemann \& I. Svendsen: The complete amino acid sequence of copper, zinc superoxide dismutase from Saccharomyces cerevisiae. Carlsberg Res. Commun. 44, 201-217 (1979)

13. Jori, G., G. Galiazzo, A. Marzotto \& E. ScofFONE: Selective and reversible photo-oxidation of the methionyl residues in lysozyme. J. Biol. Chem. 243, 4272-4278 (1968)

14. LAPPI,D. A.,F.S. ESCH, L. BARBIERI, F.STIRPE\&M. SORIA: Characterization of a Saponaria officinalis seed ribosome-inactivating protein: immunoreactivity and sequence homologies. Biochem. Biophys. Res. Commun. 129, 934-942 (1985)

15. Mahoney, W. C. \& M. A. Hermodson: Separation of large denatured peptides by reverse phase high performance liquid chromatography. Trifluoroacetic acid as a peptide solvent. J. Biol. Chem. 255, 11199-11203 (1980)

16. Mahoney, W. C., P. K. SMith \& M. A. Hermod-
SON: Fragmentation of proteins with o-iodosobenzoic acid: Chemical mechanism and identification of o-iodosobenzoic acid and a reactive contaminant that modifies tyrosyl residues. Biochemistry 20, 443-448 (1981)

17. Nilsson, L., K. Asano, B. Svensson, F. M. PoulSEN \& O. NYGÁRD: Reduced turnover of the elongation factor EF-1 ribosome complex after treatment with the protein synthesis inhibitor II from barley seeds. (submitted)

18. Ready, M. P., R. P. Adams \& J. D. Robertus: Dodecandrin, a new ribosome-inhibiting protein from Phytolacca dodecandra. Biochim. Biophys. Acta 791, 314-319(1984)

19. Ready, M., K. Wilson, M. PiataK \& J. D. RobERTUS: Ricin-like plant toxins are evolutionarily related to single-chain ribosome-inhibiting proteins from Phytolacca. J. Biol. Chem. 259, 1525215256 (1984)

20. RoBERTS. W.K. \& C.P.SELIT RENNIKOFF: Isolation and partial characterization of two antifungal proteins from barley. Biochim. Biophys. Acta 880 , 161-170 (1986)

21. ROEPSTORFF, P.: Determination of the amino acid sequence of the C-terminal cyanogen bromide fragment of myoglobin from bottle nosed dolphin by mass spectrometric peptide mixture analysis. Biomed. Mass. Spectrom. 5, 362-366 (1978)

22. RUNSWICK, M. J. \& J. E. WALKER: The amino acid sequence of the $\beta$-subunit of ATP synthase from bovine heart mitochondria. J. Biol. Chem. 258, 3081-3089 (1983)

23. StIRPE, F. \& L. BARBIERI: Ribosome-inactivating proteins up to date. FEBS Letters 195, 1-8 (1986)

24. Sundqvist, B., I. Kamensky, P. Hákansson, J. KJELlberG, M. SAlEhPour, S. Widdiyasekera, J. Fohlman, P. A. Peterson \& P. RoepstorfF: Californium-252 plasma desorption time-of-flight mass spectrometry of proteins. Biomed. Mass. Spectrom. 11, 242-257 (1984)

25. Svendsen, I., B. Martin \& I. Jonassen: Characteristics of Hiproly barley III. Amino acid sequences of two lysine-rich proteins. Carlsberg. Res. Commun. 45, 79-85 (1980)

26. Svensson, B., K. Larsen \& I. SVEndSEN: Amino acid sequence of tryptic fragments of glucoamylase G1 from Aspergillus niger. Carlsberg Res. Commun. 48, 517-527 (1983)

27. SVEnsson, B., K. LARSEN, I. SVEndSEN \& E. BOEL: The complete amino acid sequence of the glycoprotein, glucoamylase G1, from Aspergillus niger. Carlsberg Res. Commun. 48, 529-544 (1983) 